\title{
Spatio-temporal pattern of bog pine (Pinus uncinata var. rotundata) at the interface with the Norway spruce (Picea abies) belt on the edge of a raised bog in the Jura Mountains, Switzerland
}

\author{
François FrelÉchOUX ${ }^{\mathrm{a}, \mathrm{b}, c *}$, Alexandre ButTLER $^{\mathrm{b}, \mathrm{d}}$, Fritz H. SCHWEINGRUBER ${ }^{\mathrm{e}}$, Jean-Michel GobAT ${ }^{\mathrm{a}}$ \\ ${ }^{a}$ Laboratoire d'Écologie végétale et de Phytosociologie, Institut de Botanique de l’Université de Neuchâtel, \\ rue Émile-Argand 11, 2007 Neuchâtel, Switzerland \\ b WSL Antenne romande, Swiss Federal Research Institute, Case postale 96, 1015 Lausanne, Switzerland \\ ${ }^{c}$ Laboratoire d'Écologie et Évolution, Département de Biologie, Pérolles, Chemin du Musée 10, 1700 Fribourg, Switzerland \\ d Laboratoire de Chrono-écologie, UMR 6565 CNRS, UFR des Sciences et Techniques, 16 route de Gray, \\ Université de Franche-Comté, 25030 Besançon, France \\ e WSL Swiss Federal Research Institute, Zürcherstrasse 111, 8903 Birmensdorf, Switzerland
}

(Received 17 February 2003; accepted 24 April 2003)

\begin{abstract}
In a bog site in way of paludification, a pine stand is declining, which presently is an infrequent phenomenon on the Swiss Jura scale. A transect was positioned in the bog, from the external and driest part (pine-spruce stand) towards the central and wettest part (pine stand). Water table, tree structure, tree age structure and pine radial growth were analysed with spatial and temporal references. The ground water level is very shallow and the hydrologic gradient is obvious during dry periods. Tree structure (height and diameter) is strongly linked to the hydrologic gradient. Two cohorts have invaded the bog with a 70-year-time period between them. The first one concerned the whole transect; it started around 1840 and could be related to a clear cutting on the fringe of the bog. After a quick initial radial growth, the pines reduced their radial growth abruptly (1870-1885), more quickly and strongly in the centre of the bog, where an important mortality was observed over the last 10 years. Bog pine can thus survive over decades with a very reduced growth and in very wet environment. We think that the edge of raised bogs probably constituted the bog pines' survival niche during paludification in the Jura bogs.
\end{abstract}

raised bog / water table / ecotone / dendroecology / dynamics

Résumé - Réactions spatio-temporelles du pin à crochets (Pinus uncinata var. rotundata) à l'interface d'une ceinture d'épicéas (Picea abies) sur la marge d'un haut-marais de la chaîne jurassienne, Suisse. Dans un site de haut-marais en voie de paludification, un peuplement de pins dépérit, ce qui est actuellement peu fréquent à l'échelle du Jura suisse. Un transect a été établi dans la tourbière de la partie externe et sèche (peuplement mixte pin-épicéa) vers la partie centrale et très humide (peuplement de pins). La nappe phréatique, la structure des arbres, la structure d'âge des arbres et la croissance radiale des pins ont été analysées avec références spatiale et temporelle. La nappe est très superficielle et le gradient hydrique est évident lors de périodes sèches. La structure des arbres (hauteur, diamètre) est nettement liée au gradient hydrique. Deux cohortes ont envahi le marais à 70 ans d'intervalle. La première, sur l'ensemble du transect, a débuté vers 1840 et pourrait être en relation avec un déboisement à la périphérie de la tourbière. Après une croissance radiale initiale rapide, les pins ont réduit brusquement leur croissance radiale (1870-1885), plus rapidement et plus fortement au centre du marais où une forte mortalité fut observée depuis 10 ans. Les pins à crochets peuvent donc survivre durant des décennies avec une croissance très réduite en milieu très humide et nous pensons que le bord des tourbières fut probablement leur niche de survie durant la paludification des marais jurassiens.

haut-marais / nappe phréatique / écotone / dendroécologie / dynamique

\section{INTRODUCTION}

In the Jura Mountains, bog pine (Pinus uncinata Ramond var. rotundata (Link) Antoine) is found in widely different ecological situations, such as rocky limestone environments and ombrotrophic bogs. Pines are generally considered as heliophi- lous and pioneer species, but they are often found in extreme sites to where they have been relegated by other competitors [40]. In raised bogs, the bog pine has to withstand a cold climate, a high water table and nutrient-poor organic soils. Norway spruce (Picea abies (L.) Karsten) has also a large ecological range, and is found in bogs as well, but grows mainly on

\footnotetext{
* Corresponding author: francois.frelechoux@wls.ch
} 


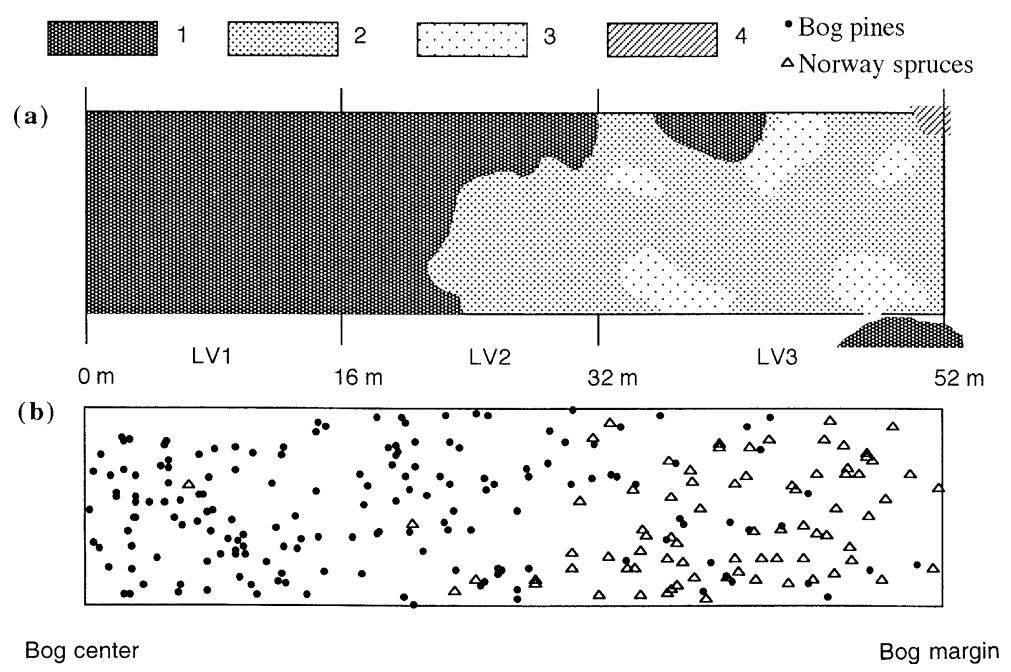

Figure 1. Main vegetation patches along the transect according to the dominant moss and herbaceous species (a) and location of the living bog pines and Norway spruces (b). 1. Wettest zone with Eriophorum vaginatum L., Sphagnum angustifolium (Russ.) C. Jens and S. fallax (Klinggr.) Klinggr.; 2. Drier zone with Vaccinium myrtillus L., Sphagnum angustifolium (Russ.) C. Jens, S. fallax (Klinggr.) Klinggr., and Polytrichum commune Hedw.; 3. Driest zone with low cover of moss and herbaceous species and with spruce litter; 4. Marginal zone with Sphagnum girgensohnii Russ. Subplots are LV1: low pine stand in the wettest zone (bog centre); LV2: intermediate pine stand; LV3: tall mixed pine and spruce stand in the driest zone (bog margin).

shallow peat soils near the bog edge or on dry cut-over surfaces, often together with pubescent birch (Betula pubescens Ehrh.). It can be found in many other sites of the Jura Mountains where it contributes to various forest vegetation types [6, 39]. Norway spruce can act as a pioneer species [33], as a post-pioneer, or as a late successional one [37]. Unlike bog pine, its seeds can germinate and survive even in shaded undergrowth, but it is not able to withstand extremely wet and oligotrophic conditions in bogs [16].

In the Jura Mountains, raised bogs are generally not very large, most of them are smaller than 20 ha, which is typical in a karst environment that limits their development. The growth dynamics of the Jura bogs has been considerable during the postglacial period, with several meters of peat having built up. Most of the bogs in Switzerland have been drained and cut mainly between the 18th and the middle of the 20th century. Drainage of peat bogs can trigger bog pine invasion and affect the structure of tree populations and tree growth [16, 17]. Vegetation changes on uncut surfaces have often occurred as an indirect result of peat cutting in the vicinity $[16,18]$. Thus, the pinewood development on a large scale in the Jura bogs may represent a recent phenomenon. Extension of tall pinewood stands has been observed after the Jura bogs were affected by drainage [17]. This is confirmed by Hubschmid and Lang [23], Joray [25] and Reille [38], who emphasized that there has been a drastic increase in pine pollen abundance in the recent past within peat profiles, although pine (Pinus spp.) stands are rather scattered throughout the Jura region. In some rare situations, due to anthropic disturbance, a succession from bog pine to Norway spruce stands can occur [19].

Paludification is generally known as the process by which the forest becomes peatland. Whereas today most of the raised bogs in Switzerland are going through a drying phase with pine trees expanding onto their inner parts, on the Les Veaux bog there is an active paludification. Its water level is high and the current stand of bog pine is declining in the central part of the bog. Thus, the Les Veaux bog provides an ideal opportunity to study tree reactions in relation to the high water table. This paper aims to: (i) compare the structural characteristics of bog pine and Norway spruce trees along a hydrological gradient at the edge of an unexploited bog in the Jura Mountains, (ii) show the colonisation dynamics of these populations, (iii) reconstruct the populations' radial growth, (iv) relate dendroecological measurements to historical events, and (v) relate dendroecological measurements to the main hydrologic gradient and to undergrowth vegetation.

\section{METHODS}

\subsection{Study site and vegetation}

The dendroecological study was carried out along the edge of the Les Veaux bog (co-ordinates $47^{\circ} 14^{\prime} 34^{\prime \prime}$ N, 07 05' 40' ' E; $1015 \mathrm{~m}$ a.s.1.) in the area of Les Genevez, situated in the Franches-Montagnes uplands. The mire has a surface of 7 ha and can be considered a pristine bog [20]. Most of the surface is colonised by scattered bog pines, whereas the Norway spruce stand forms a dense belt around the bog $[15,16]$. Despite a peat thickness of only $1 \mathrm{~m}$, the lowest layers are thought to date back to the subboreal period (ca. 2900BP) [14]. The impermeable bedrock is a tertiary deposit [14].

In this part of the Jura range, mean annual precipitation is about $1500 \mathrm{~mm}$ with a peak in summer. Mean annual temperature is about $5.5^{\circ} \mathrm{C}$; the mean of the coldest month (January) is ca. $-4{ }^{\circ} \mathrm{C}$, and the mean of the warmest month (July) is ca. $13{ }^{\circ} \mathrm{C}$ [16].

In the herbaceous layer of the wettest part of the transect (LV1, LV2 - bog centre; Fig. 1), meso-oligotrophic species such as Carex rostrata Stokes, C. echinata Murray, and C. curta Gooden. were found together with more oligotrophic species such as Eriophorum vaginatum L., Carex pauciflora Light., Vaccinium oxycoccos L. and Andromeda 
polifolia L., while Vaccinium myrtillus L. dominated in the driest part (LV3 - bog margin). Sphagnum angustifolium (Russ.) C. Jens and S. fallax (Klinggr.) Klinggr. dominated the moss layer along the transect while Polytrichum commune Hedw. and Sphagnum girgensohnii Russ. were found on the bog margin. According to several authors [14, 42], this bog has probably evolved within the last centuries from a minerotrophic mire.

\subsection{Sampling transect and water table monitoring}

In order to investigate dendroecological reactions of spatially referenced trees we chose only one transect measuring $52 \mathrm{~m}$-long and $12 \mathrm{~m}$ wide which was positioned perpendicularly to the edge of the bog along the main hydrologic gradient. It was representative of the whole site of Les Veaux which has a uniformly flat surface and the same tree height gradient from the spruce edge forest around the bog to the lower and declining pine stand in the centre. The transect crossed the entire ecotone at the mire margin including the interface bog pine stand - Norway spruce stand. The transect was subdivided into three parts according to tree structure and composition (Fig. 1): a drier part at the margin (LV3) comprising a mixed pine-spruce stand and a wetter part comprising a bog pine stand with some chlorotic spruces. The latter was subdivided in two equal parts, LV1 in the mire centre and LV2 in the intermediate situation. The locations of all trees along the sampling transect were mapped.

As the soil surface was relatively flat on the whole transect, without a distinct hummock-hollow topography, we placed randomly 5 piezometers in each of the transect's subplots (LV1, LV2, LV3). Depth to water table was measured weekly during the season 1995 (every second week from mid Septembre to mid October). For each measurement date, non-parametric Kruskal-Wallis tests were performed to compare differences between plot values. A duration curve represents the cumulative number of days on which the ground water is above a certain level and daily data were calculated using linear interpolations based on measurements of two successive weeks.

\subsection{Structure of tree stands}

In 1995, all the individual trees, both living and dead, apart from the few youngest saplings ( $<4$ years old), were mapped and numbered and their main morphological characteristics recorded. Their density was calculated for each subplot. Height was measured directly with a folding pocket rule for the small trees or with a clinometer (Suunto) for taller individuals. Diameter and basal area were calculated from the circumference at the stem base. The tall trees were cored at 15 to $40 \mathrm{~cm}$ above the ground with an increment core borer (one or two cores were taken), whereas small trees and saplings were cut and sliced at their root collar. This material was prepared in the laboratory to obtain information on the age of each tree and to allow the construction of skeleton plots. Mean annual apical growth of each tree was calculated as the ratio between corrected height (tree height minus coring height) and age read at coring height. Age underestimation due to coring above the collar was assessed for each tree by dividing coring height by mean annual apical growth. Mean age underestimation was 3 years for living spruces and, 6, 8 and 5 years for living bog pines in the subplots LV1, LV2, LV3, respectively. For living pines only, statistical differences of height, diameter, age, and mean annual apical growth, were performed with non-parametric Kruskal-Wallis tests (3 subplots) and Mann-Whitney tests (paired comparisons between subplots) if previous were significant.

\subsection{Skeleton plot}

Developed by Douglas [13] and later by Stokes and Smiley [45], this method of visual reading was used by Schweingruber et al. [41] for ecological analysis. It allows the recognition of characteristic rings (e.g. event years based on abrupt growth changes) of single trees and it permits to determine characteristic years (pointer years), which represent the reaction of a whole stand. It also allows growth curves to be produced for stands based on individual growth indices determined by abrupt growth changes $[41,47]$. We have used the skeleton plot method for the following reasons: (1) Although trees in bogs are less sensitive to environmental changes, ring sequences tend to show good signatures, e.g. latewood event years, which permit good cross-dating between bog pines. (2) Increase or decrease event years based on abrupt growth changes can be used as high frequency signals which may be interpreted in relation to climate, to human disturbances such as drainage [17], to unfavourable hydrologic conditions (this issue), or to take in evidence tree stand succession [19]. (3) Abrupt growth change curves maximise medium-term fluctuations, so that high-frequency signals are suppressed. These measurements are essential for the reconstruction of bog dynamics, which would be more difficult to demonstrate on measured, continuous ring-width sequences. Visual readings were carried out with a stereomicroscope (Olympus SZ-ST) equipped with a micrometric eyepiece $(0.05 \mathrm{~mm}$ graduations). Data handling, calculations, and graphical display followed Weber [46].

\subsection{Abrupt growth changes (AGC) and abrupt growth change mean (AGCm) curve}

The construction of a skeleton plot of each tree is based on abrupt growth changes, which can be recognised and quantified by successively comparing all the ring widths. The largest ring is taken as a reference in each radius [41]. Each ring is assigned to a radial growth reduction class, based on measurements where: class 0 is for those with $0-40 \%$ of reduction, class -1 for $40-55 \%$, class -2 for $55-70 \%$, and class -3 for $>70 \%$. Thus, two successive abrupt growth changes are separated by a period of relatively constant and homogeneous growth of the tree and the successive rings belong to the same class reduction (AGC single value). Abrupt growth change mean curve (AGCm curve) was based on annual values and was the mean of all AGC single values of all bog pines of the transect, using the median percentage values (for the reduction class $0: \mathrm{x}_{0}=0.8$, which means $80 \%$ of the maximum growth observed in a radius; for the class reduction $-1: \mathrm{x}_{-1}=$ $0.525 ; x_{-2}=0.375 ; x_{-3}=0.15$ ). One or two radii per tree served to establish the AGCm curve. Further details are available in Freléchoux et al. [17].

\subsection{Cartographic interpolation}

The height and the mean annual apical growth of the dominant trees (bog pines and Norway spruces) are represented on interpolated maps. Within each subplot, only individual trees taller than the median height were used. Single AGC values, i.e. the median percentage values, or their mean values when two radii were read for a single tree, were interpolated for each year from 1880 to 1884 . Cartographic interpolation and representation were performed with the McGridzo software package (RockWare Inc., Wheat Ridge, Colorado, USA, 1990), using a grid $2 \mathrm{~m}$ long and $1 \mathrm{~m}$ wide. For each node of the grid, $\mathrm{z}$ values were based on the 5 nearest trees, weighted with the square of inverse of distance to the node.

\subsection{Grouping according to spatial contiguity}

Multivariate numerical analysis was used to detect discontinuities along the transect, based on the information given by the abrupt growth changes. AGC single values, i.e. the median percentage values (or the mean values when two radii were read for a single tree) for the years between 1880 and 1995 were used as descriptors for calculating the Euclidean distance matrix comparing all the individual trees. Prior to the analysis, the data were standardised (zero mean and unit variance). Based on the similarity transformed distance matrix, a clustering according to spatial contiguity [26] was performed, using bi-dimensionally 


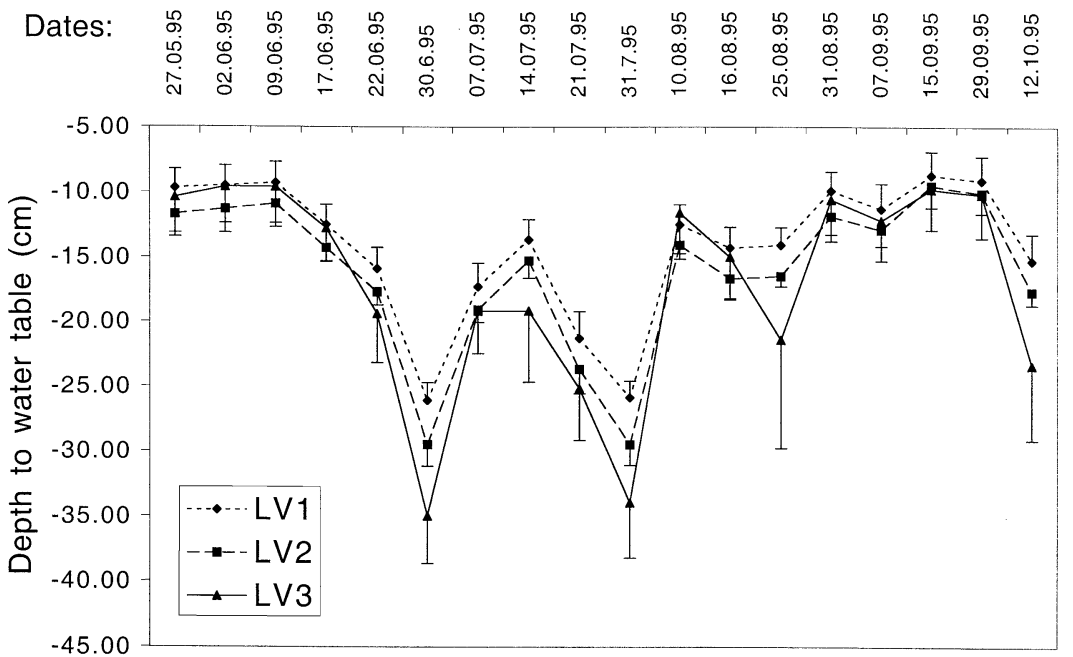

Figure 2. Measurements (mean and one SD) of depth to water table during 1995. Differences between subplots were significant with KruskalWallis tests only in the driest periods: $30.6 .95(p=0.0055), 31.7 .95(p=0.0045), 25.8 .95(p=0.0300), 12.10 .95(p=0.0147)$.

constrained, proportional-link linkage clustering (program BIOGEO in "R" package - Legendre and Vaudor [27]). Delaunay's triangulation links between the geographical position of the trees, calculated with the program CONNEXION of the "R" package, served as spatial constraint.

\section{RESULTS}

\subsection{Depth to water table}

In the Les Veaux bog, the water table was very shallow (Figs. 2 and 3) and showed a weak gradient during the whole season between LV1 (average $=-14.2 \mathrm{~cm} ; 1 \mathrm{SD}=5.5 \mathrm{~cm}), \mathrm{LV} 2$ $(\mathrm{AV}=-16.2 \mathrm{~cm} ; 1 \mathrm{SD}=6.0 \mathrm{~cm})$ and LV3 $(\mathrm{AV}=-17.1 \mathrm{~cm}$; $1 \mathrm{SD}=8.7 \mathrm{~cm})$. Differences were not significant during wet periods between plots but they became clearly significant during the driest periods (Figs. 2 and 3).

\subsection{Structure of tree stands}

Dead bog pines were found to be numerous in the wettest part (mire centre, subplot LV1) of the transect (Tab. I), whereas spruces were almost entirely absent. In the intermediate subplot LV2, there were still some dead bog pines, whereas Norway spruces were more frequent, even if they were small and chlorotic. Living spruce density increased drastically towards the edge of the bog (LV3), whereas density of living bog pine decreased regularly from the wettest part (LV1) to the driest one (LV3). The basal area of Norway spruce increased from the wettest subplot towards the drier ones at the edge of the bog. For the living bog pines, the maximum basal area was found in the middle of the transect (LV2). Tree descriptors were significantly different between subplots (all K.-W. tests with $p<$ 0.05 ) and paired comparisons (all M.-W tests with $p<0.05$ ), except the age of pine of LV1 and LV2, indicating a clear gradient for height, diameter and mean annual apical growth from

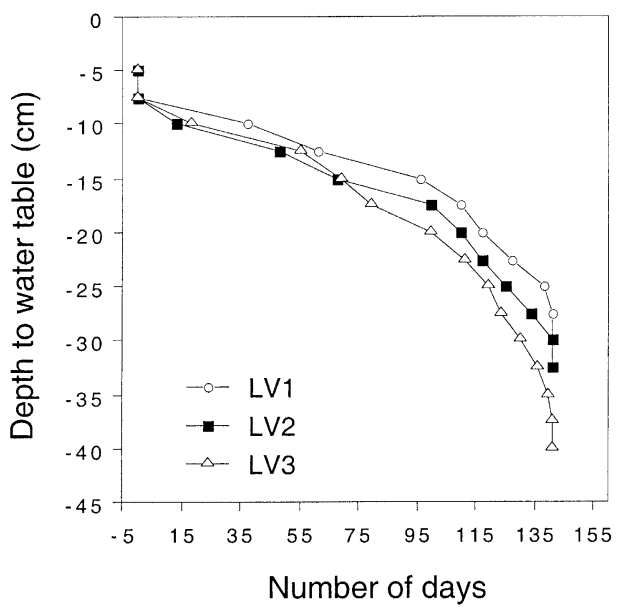

Figure 3. Duration curves of the ground-water table in the three subplots of the transect showing the cumulative number of days on which the ground water is above a certain level.

the centre of the bog towards the margin. The bog pines of subplot LV3 grew on average three times faster than those of the wettest subplot and their apical growth rates were, on average, higher than those of the spruces. They were on average taller and of larger diameter than the spruces which is due to their better apical growth.

The height of the dominant bog pines and Norway spruces showed a clear gradient, with the tallest trees on the driest side of the transect (Fig. 4). The isoline of $9 \mathrm{~m}$ runs approximately along the pine-spruce contact zone and along the main limit between undergrowth vegetation patches (Fig. 1). It is also at this interface that the mean annual apical growth was highest (Fig. 5), the maximum growth rate being $19.3 \mathrm{~cm} \cdot \mathrm{yr}^{-1}$ for pine and $18.0 \mathrm{~cm} \cdot \mathrm{yr}^{-1}$ for spruce. 


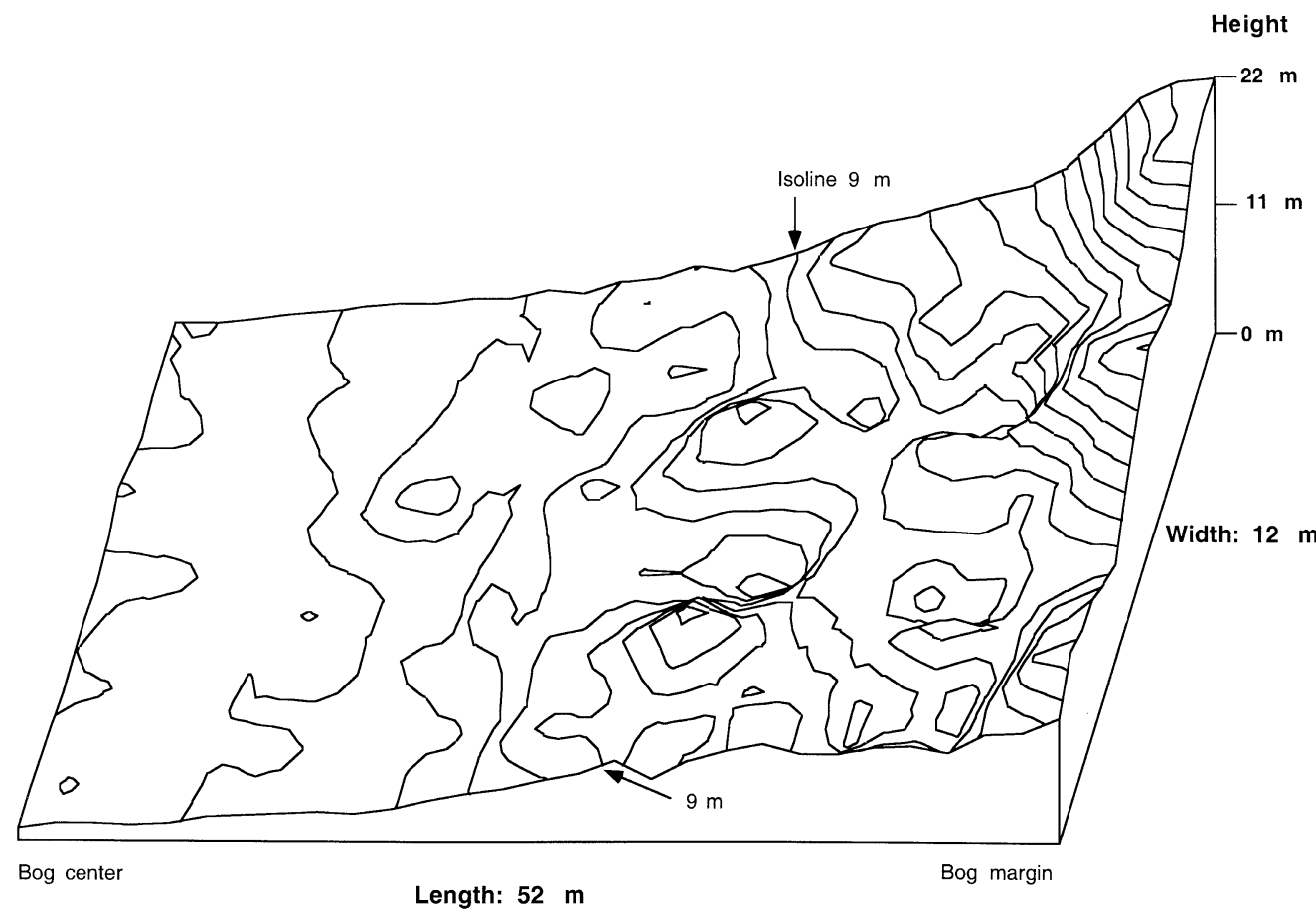

Figure 4. Three-dimensional map of the height of dominant living bog pines and Norway spruces together on the transect. Isolines of 1 metre are represented. Different scales are used for the three axes. The isoline $9 \mathrm{~m}$ runs approximately along the pine-spruce contact zone and along the main limit between undergrowth vegetation patches. Tree height gradient is weak in the wetter part of the transect (pine stand), but increases abruptly in the driest part (spruce stand).

Table I. General characteristics of the tree stands in the three subplots of the transect. For tree descriptors, mean and 1SD (in brackets) are given. Significant statistical differences between groups (LV1, LV2, LV3) are given with different letters $(p<0.05)$.

\begin{tabular}{|c|c|c|c|c|c|c|c|c|c|}
\hline \multirow[b]{2}{*}{ Subplot } & \multirow[b]{2}{*}{ Species } & \multirow[b]{2}{*}{ Status } & \multicolumn{3}{|c|}{ Stand descriptors } & \multicolumn{4}{|c|}{ Tree descriptors } \\
\hline & & & Number & $\begin{array}{c}\text { Density } \\
\left(\text { trees }^{\prime} \mathrm{ha}^{-1}\right)\end{array}$ & $\begin{array}{c}\text { Basal area } \\
\left(\mathrm{m}^{2} \cdot \mathrm{ha}^{-1}\right)\end{array}$ & $\begin{array}{l}\text { Height } \\
(\mathrm{m})\end{array}$ & $\begin{array}{l}\text { Diameter } \\
(\mathrm{cm})\end{array}$ & $\begin{array}{l}\text { Age } \\
(\mathrm{yr})\end{array}$ & $\begin{array}{l}\text { Mean annual apical growth } \\
\qquad\left(\mathrm{cm} \cdot \mathrm{yr}^{-1}\right)\end{array}$ \\
\hline \multirow[t]{4}{*}{$\overline{\mathrm{LV} 1}$} & Bog pine & Living & 83 & 4323 & 21.9 & $3.20(1.58) \mathrm{A}$ & $7.1(3.8) \mathrm{A}$ & 104 (42) A & $3.39(1.87) \mathrm{A}$ \\
\hline & & Dead & 43 & 2240 & - & - & - & - & - \\
\hline & Norway spruce & Living & 1 & 52 & $\approx 0$ & $0.15(-)$ & $0.3(-)$ & $9(-)$ & $1.67(-)$ \\
\hline & & Dead & 0 & 0 & - & - & - & - & - \\
\hline \multirow[t]{4}{*}{ LV2 } & Bog pine & Living & 57 & 2969 & 33.0 & $5.08(2.25) \mathrm{B}$ & 10.8 (5.1) B & 107 (38) A & $4.80(2.64) \mathrm{B}$ \\
\hline & & Dead & 15 & 781 & - & - & - & - & - \\
\hline & Norway spruce & Living & 8 & 417 & 1.7 & $2.21(2.72)$ & $5.0(5.7)$ & $49(26)$ & $4.25(4.41)$ \\
\hline & & Dead & 0 & 0 & - & - & - & - & - \\
\hline \multirow[t]{4}{*}{ LV3 } & Bog pine & Living & 27 & 1125 & 30.5 & $7.62(4.73) \mathrm{C}$ & $15.4(10.6) \mathrm{C}$ & 72 (42) B & $9.57(5.15) \mathrm{C}$ \\
\hline & & Dead & 2 & 83 & - & - & - & - & - \\
\hline & Norway spruce & Living & 72 & 3000 & 44.4 & $5.68(5.55)$ & $9.9(9.6)$ & $83(40)$ & $5.72(4.38)$ \\
\hline & & Dead & 1 & 42 & - & - & - & - & - \\
\hline
\end{tabular}

Bog pine appears to have colonised in two successive cohorts (Figs. 6 and 7): the first and most important one occurred after 1840, and a second one occurred after 1930. Pine height of the first cohort reflected their position along the transect (Fig. 7).
The scatterplot age-height (Fig. 7) showed that along the mire margin, as well as to some extent in the intermediate zone, the younger cohort of bog pine was fast growing. When analysing the mixed tree stand of subplot LV3 (Fig. 8), it appeared that both 


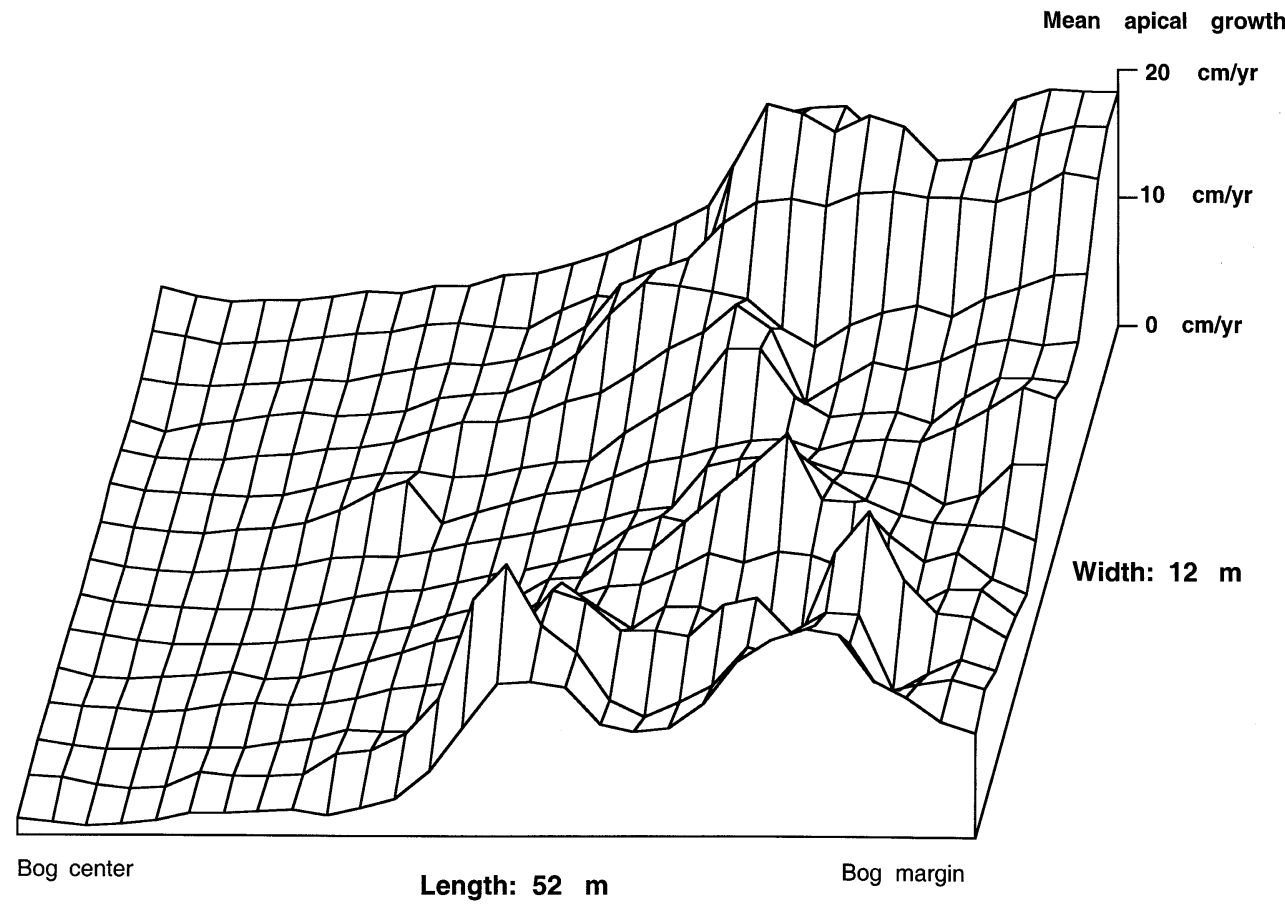

Figure 5. Three-dimensional map of mean apical annual growth of dominant living bog pines and Norway spruces together on the transect. Different scales are used for the three axes.

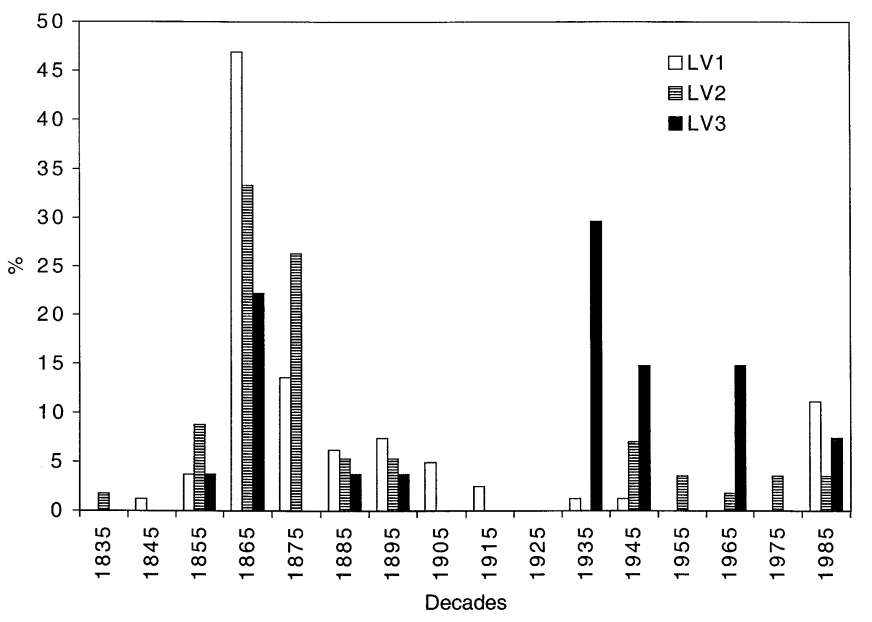

Figure 6. Living bog pine colonisation between 1830 and 1990 in the 3 subplots of the transect, given in \% of the total number of individuals in each subplot.

tree species colonised the bog margin with two synchronous cohorts in response to the same ecological constraints. The scatterplot age-height for both species in the subplot LV3 (Fig. 9) showed that the bog pines of the first cohort, mostly located in the driest part of the transect, were of equal height. They tended to stay in the undergrowth of the spruce, which varied more in height. In the second cohort the population structure of both species was similar.

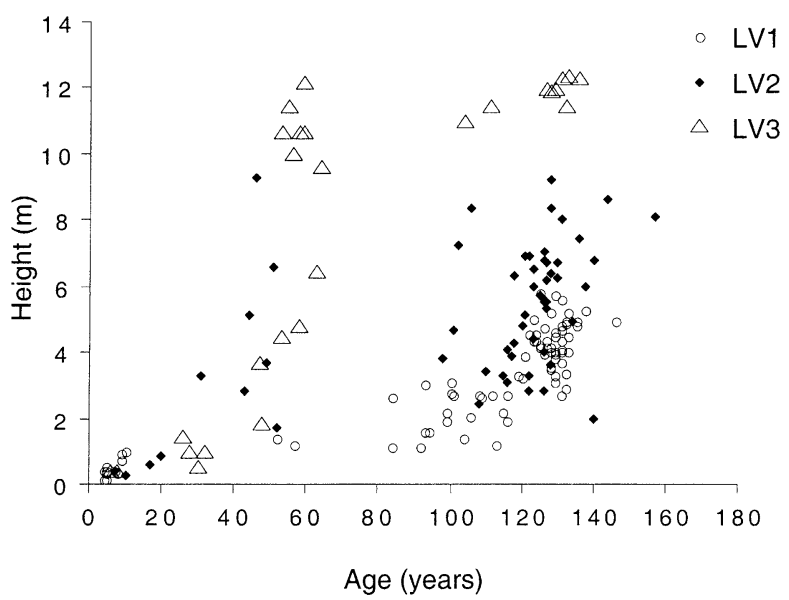

Figure 7. Scatterplot age-height for living bog pines in the three subplots of the transect. Pine colonisation occurred in two successive cohorts. Mainly for the first cohort, pine height depended on the location in the transect.

\subsection{Tree radial growth and spatial pattern}

The radial growth of both dead and living pines was fast along the whole transect between 1859 and 1885 (Fig. 10a), but before that period, growth was very slow in LV1 + LV2, as indicated by the few old trees (Fig. 10b). The drastic reduction in growth after 1880 started along the wetter side of the transect (Fig. 10a), as also represented on the spatio-temporal maps of 


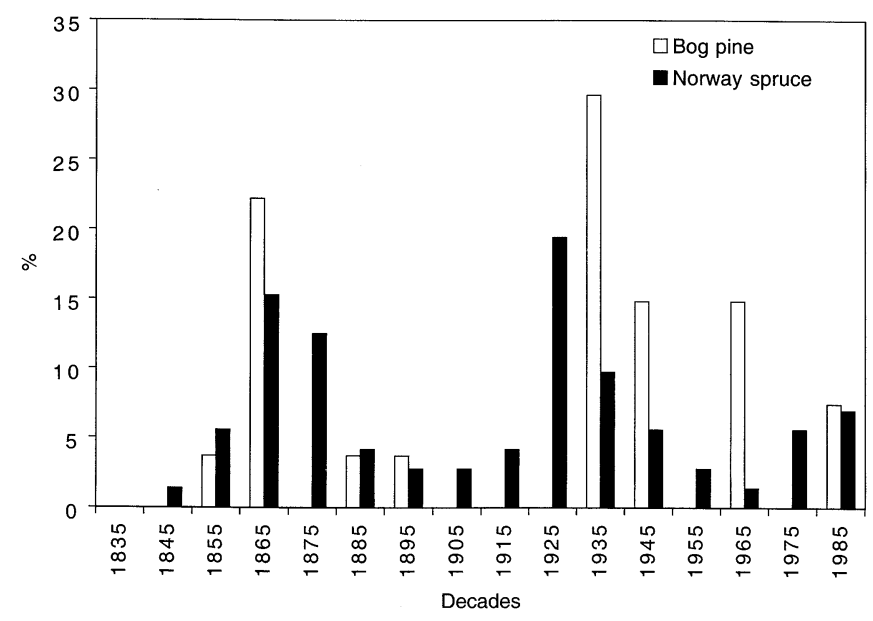

Figure 8. Living bog pine and Norway spruce colonisation between 1840 and 1990 in the mixed stand of the subplot LV3, given in \% of the total number of individuals for each species. In response to the same ecological constraints, both tree species colonised the bog margin with two synchronous cohorts.

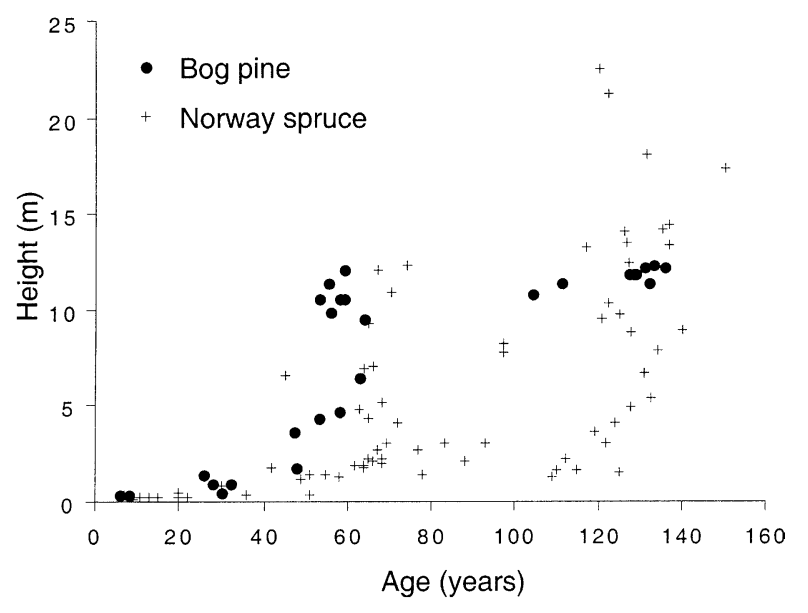

Figure 9. Scatterplot age-height for living bog pines and Norway spruces in the mixed stand of subplot LV3. In the oldest cohort, height patterns differed clearly between species, pines being of the same height, spruces showing a great height range. In contrast, trees of the second cohort showed the same pattern.
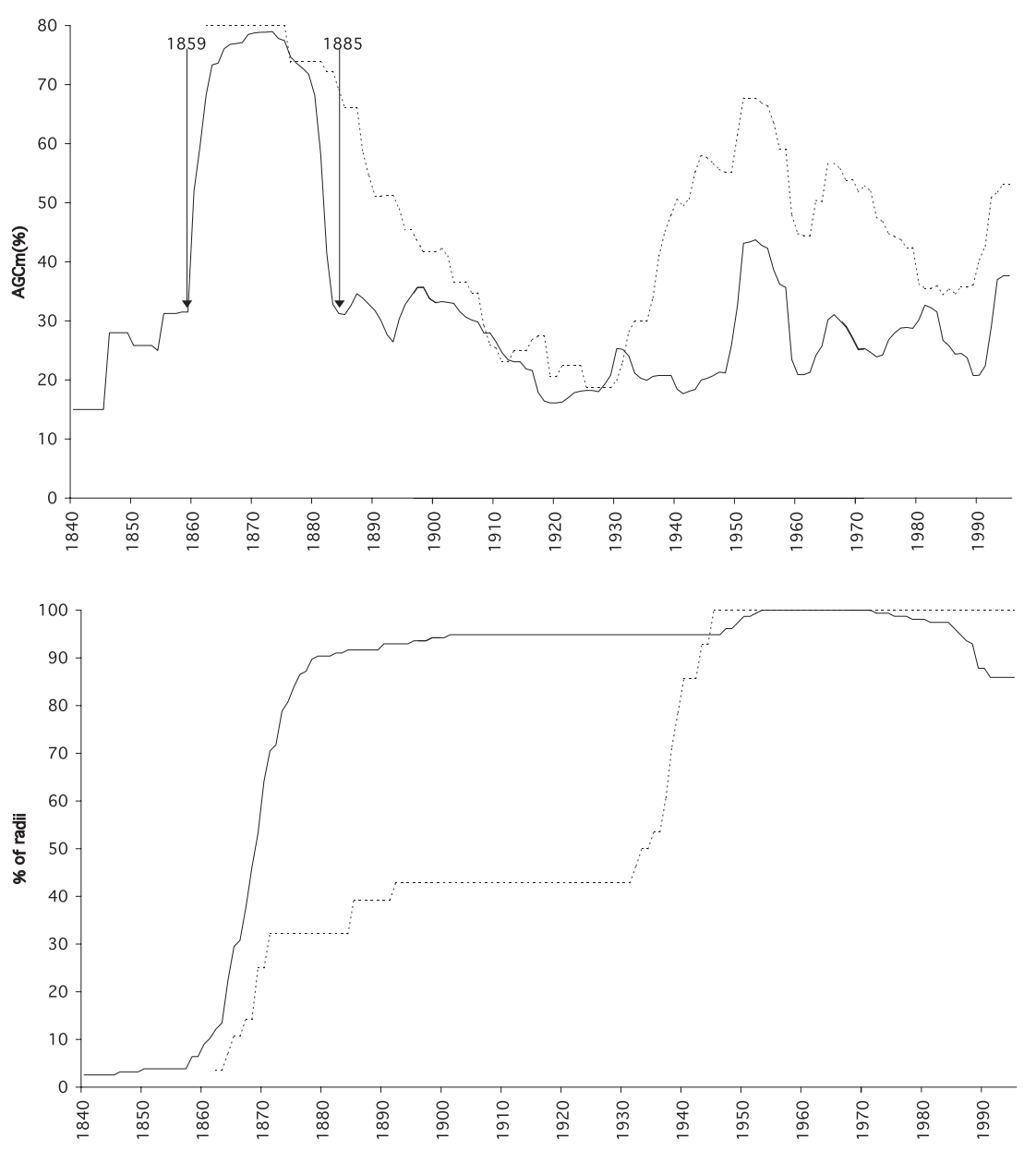

a

b

Figure 10. Abrupt growth change means (a) of bog pines on the transect and total number of radii read (b), given in \%. LV1 + LV2 (continuous line) and LV3 (dotted line) are presented separately. Before 1870 AGCm curve interpretation is less reliable since it is based on few radii. Although AGCm curves showed the same trend, growth reduction was stronger (e.g. after 1880) and growth recovery weaker (e.g. before 1950) in the wettest part of the transect (LV1 + LV2) in comparison to the driest part (LV3). 


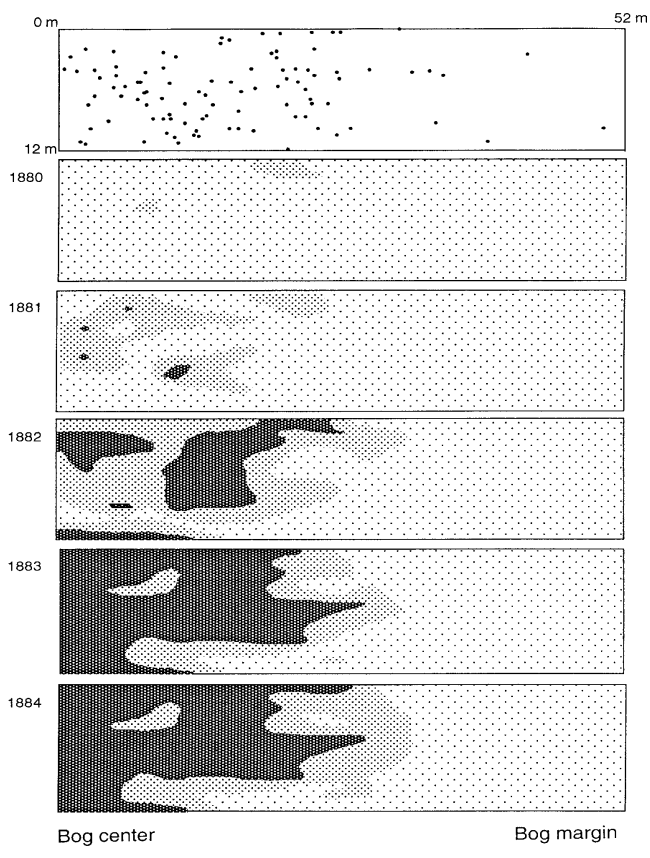

Figure 11. Two-dimensional maps of the annual radial growth reduction values given by abrupt growth change measurements of living and dead bog pine on the transect. Successive event years of the growth reduction period between 1880 and 1884 are given. The upper map represents the location of the bog pines. Dense shaded: $<30 \%$ of maximum growth; intermediate shaded: between 30 and $50 \%$ of maximum growth; light shaded: $>50 \%$ of maximum growth. AGCm growth reduction for pines was stronger in the wettest part of the transect.

annual abrupt growth change values of bog pine trees on the transect (Fig. 11). The growth recovery before 1950 was better in the dryer part of the transect (Fig. 10a). When using the multivariate information of abrupt growth changes of bog pines to cluster individual trees according to spatial contiguity (Fig. 12), a clear discontinuity appears across the transect, approximately along the boundary of the Norway spruce population and corresponds well with the main gradients in tree height structure (Fig. 4) and undergrowth vegetation in the transect (Fig. 1). Bog pine trees in the driest part of the transect cluster already at a higher fusion level, whereas trees in the wetter part of the transect tend to cluster at a lower one, indicating that they grow with a more diverse radial growth pattern.

\section{DISCUSSION}

\subsection{Depth to water table and tree survival}

While raised bogs in the Jura Mountains present usually a bulky peat deposit (up to $10 \mathrm{~m}$ ) and are generally in a drying up phase with encroachment of pines, the bog of Les Veaux is different. It lies on a very thin peat layer (about $1 \mathrm{~m}$ ) and undergoes at present a period of paludification. The living Sphagnum layer does not show the usual alternation of hummocks and hollows as do mature bogs. On the centre of the bog (LV1 and LV2), the moss carpet of the fast growing Sphagnum angustifolium (Russ.) C. Jens. and S. fallax (Klinggr.) Klinggr. is very flat and the water table is particularly high, ranging more often

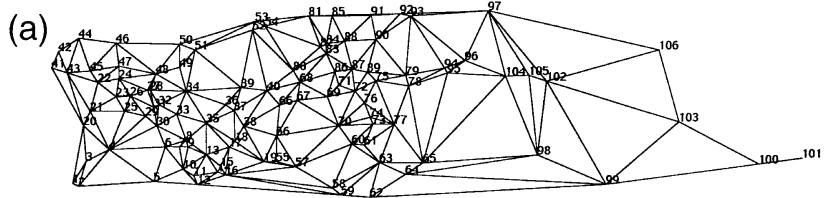

(b)

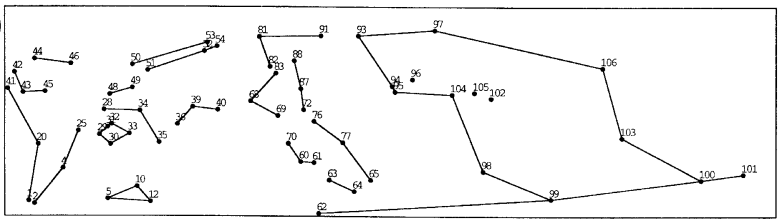

(c)

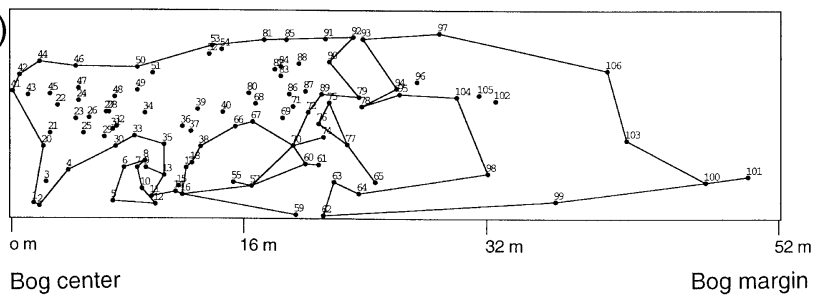

Figure 12. Clustering map according to spatial contiguity of living and dead bog pines on the transect based on the annual growth reduction values of abrupt growth change measurements of the individual trees in the period 1880-1995. Spatial constraints are given by the Delaunay's triangulation (a); maps of the fusion level at 0.85 (b) and 0.70 (c) are given. Connexity of proportional-link linkage clustering was 0.5 . The main limit between groups (see c) corresponds well with the main gradients in tree species composition, tree height structure and undergrowth vegetation along the transect.

between -10 and $-20 \mathrm{~cm}$. The decline of pines suggests that trees are currently under intense water stress.

In mires, the water table is an important factor which limits tree development. Its influence on the survival and growth of seedlings has been shown for several bog tree species $[21,28$, 29]. Aeration of the upper soil layer has also been shown to be critical for many species, either at the seedling stage or later for the adult plants $[4,8,10,11]$. This is because the oxygen transport ability within the woody roots affects the way a plant adapts to waterlogging $[35,36]$. Consequently, drainage improves the growth of bog trees [12, 34, 44].

We reported in other Jura sites mean water levels ranging between $-13 \mathrm{~cm}$ in the middle of the bogs and $-31 \mathrm{~cm}$ at their margin [17]. We already noted a decline of tall pines $(20 \mathrm{~m})$ at the bog margin in one site where the water level was particularly high $(-17 \mathrm{~cm}$ in average). In the Les Veaux bog, water table differences within the transect were weak in wet periods, but increased significantly when the water table sank during dry periods in summer and autumn 1995. The drying up of the bog margin is likely due to strong evapotranspiration of trees, not balanced with rainfall. Thus, frequency and length of dry periods during the vegetation growth season could be key factors promoting the establishment and the survival of pine trees with their mycorrhizae in the central part of bogs.

\subsection{Canopy structure and tree growth}

In raised bogs of the Jura, we already observed a clear gradient of tree structure from the middle towards the margin of 
bogs which reflects clearly the water level regime [17]. At Les Veaux, the same gradient was observed and the interpolated map of the canopy showed furthermore a break in the tree structure where the pine stand comes into contact with the spruce stand. Mean apical growth for pines in other Jura sites ranged between $2 \mathrm{~cm} \cdot \mathrm{yr}^{-1}$ in the middle and $11 \mathrm{~cm} \cdot \mathrm{yr}^{-1}$ at the margin of bogs [17]. While the same gradient with a narrower range of the means (3.4-9.7 $\mathrm{cm} \cdot \mathrm{yr}^{-1}$, Tab. I) was observed for pines at Les Veaux, some highest individual values (near $20 \mathrm{~cm} \cdot \mathrm{yr}^{-1}$ ) were found for both pines and spruces at the contact zone between these two stands.

\subsection{Disturbances in bogs and tree dynamics}

Disturbances, climatic fluctuations and competition between cohorts of tree species are important factors for tree recruitment. They may alter the classical patterns recognised in stable tree stands, as demonstrated by Ågren et al. [1], Ågren and Zackrisson [2], and Lorimer [30]. Even-aged populations are indicative of a previous strong disturbance event [7, 30]. In Jura bogs, the observed age structure indicates mainly anthropic disturbances, i.e. drainage and peat cutting [17]. In Les Veaux, it seems obvious that the simultaneous settlement of trees on the whole transect after 1840 was in relation to a disturbance event. Since this site has not been exploited for peat [20], the real origin of this disturbance remains conjectural. The maximal rate of pine pollen deposition in the peat of this site was determined by Fankhauser [14] near $-40 \mathrm{~cm}$ and the nearest dating with ${ }^{210} \mathrm{~Pb}[3,14,43]$ was $1886 \pm 15$. Indeed, this corresponds well to the occurrence of the first cohort of pine and especially its maximal growth near 1880. In most bogs of the Jura Mountains, pine pollen deposition rates have increased drastically over the recent past centuries [23-25, 32, 38]. According to several authors $[5,38]$ this is related to past human activities such as drainage and peat cutting. Even without archives or historical data, it is reasonable to consider that a clear cutting took place on the fringe of the Les Veaux bog in order to create pasture lands. Based on another study in the Jura, Mitchell et al. [32] and Buttler et al. [9] hypothesised that large scale clear cuttings around Jura bogs could have enhanced pine encroachment. Indeed, increasing draught could promote the evapotranspiration of the dense Sphagnum carpet, causing a lowering of the water table at least during the driest part of the year, and hence allow subsequent modifications of the vegetation and in particular tree establishment.

\subsection{Tree growth in relation to disturbance versus climate}

Based on several dendroecological surveys in Jura bogs, we emphasised $[17,19]$ that pine invasion and growth was strongly linked with the history of anthropic, site specific disturbances. Initial radial growth of pine was fast, particularly in driest situations [17, 19], near the edge of bogs; the growth curves then declined and varied with common fluctuations between sites in relation to regional climates [17]. In Les Veaux, tree invasion occurred around 1840; initial radial growth of pines was maximal near 1880 and decreased then on the whole transect, but it depended on pine location, being faster in response to wetter conditions at the bog centre. The lowest growth observed at 1920 and the later increases of 1950 and 1990 are climatic signatures, which were already observed in three other sites [17]. A second cohort settled approximately 70 years later but this happened only at the pine-spruce contact zone. This tends to prove that the centre of the bog became already too wet and that the bog margin became too shady to promote further tree recruitment. Although some authors $[15,38]$ hypothesised that bog pine might have been planted in bogs, we think on the contrary that this invasion dynamics was natural in Les Veaux. It is in accordance with the occurrence of small innermost tree rings in the first years after settlement observed in the cores of some pines. Furthermore, we think that transplanted trees would not have survived in such wet conditions unless the environmental conditions changed, i.e. the bog dried and the water table sank.

\subsection{Primeval niche of bog pine and projection of pine stands into the future}

Despite the survival capacity of bog pine in extreme wet environments, these observations emphasise that bog pine does not withstand very shallow water table and that the intense peat growth of most Jura bogs during the rainiest periods was not favourable to this species. Nevertheless, during these periods, it may have survived in reduced populations mainly near the bog margins.

In Jura bogs, plant species of hollows and wet lawns become rarer and scarcer; they are clearly threatened by the centripetal dynamics of pines of allogenic and autogenic origins and the subsequent drying up of the peat. In relation with climatic change and increasing temperatures [22], it is not excluded that increasing summer temperatures will enhance pine evapotranspiration and accelerate further new centripetal dynamics. Since mires and bogs are under full protection in Switzerland since 1991, there is currently no more risk of new anthropic drainages and subsequent lowering of the water table. In order to rewet some central parts of bogs with their endangered vegetation and to prevent new encroachments of pines, some experiences of drain closing and pine removal were recently performed in the Swiss Jura [31].

Following the vegetation survey in pine stands of raised Jura bogs [18] and the study of pine stand structure and growth in relation to anthropic factors [17], dendroecological investigations in Les Veaux pointed out how this species is able to withstand a shallow table during several decades. Furthermore they showed the great interest in investigating tree reactions of spatially referenced trees of small populations in relation to environmental factors.

Acknowledgements: This research is part of the $\mathrm{PhD}$ thesis of F.F. and was funded by the Swiss National Research Fund (Grant No. 3134047.92). The authors thank J. Moret for statistical advice. They are also grateful to the anonymous reviewers for valuable comments on the manuscript and to S. Dingwall, B. Corboz, and A. Robinson for translation supervision. 


\section{REFERENCES}

[1] Ågren J., Isakson L., Zackrisson O., Natural age and size structure of Pinus sylvestris and Picea abies on a mire in the inland of northern Sweden, Holarct. Ecol. 6 (1983) 228-237.

[2] Ågren J., Zackrisson O., Age and size structure of Pinus sylvestris populations on mires in central and northern Sweden, J. Ecol. 78 (1990) 1049-1062.

[3] Appleby P.G., Shotyk W., Fankhauser A., Lead-210 dating of three peat cores in the Jura Mountains, Switzerland, Water Air Pollut. 100 (1997) 223-231.

[4] Armstrong W., Booth T.C., Priestly P., Read D.J., The relationship between soil aeration, stability growth of Sitka spruce (Picea sitchensis (Bong.) Carr.) on upland peaty gleys, J. Appl. Ecol. 13 (1976) 585-591.

[5] Bégeot C., Richard H., L'origine récente des peuplements de Pin à crochets (Pinus uncinata Miller ex Mirbel) sur la tourbière de Frasne et exploitation de la tourbe dans le Jura, Acta Bot. Gall. 143 (1996) 47-53.

[6] Bert G.D., Les principaux types de sapinières (Abies alba Mill.) dans le massif du Jura (France et Suisse). Étude phytoécologique, Ann. Sci. For. 49 (1992) 161-183.

[7] Bergeron Y., Gagnon D., Age structure of red pine (Pinus resinosa Ait.) at its northern limit in Quebec, Can. J. For. Res. 17 (1987) 129-137.

[8] Boggie R., Water-table depth and oxygen content of deep peat in relation to root growth of Pinus contorta, Plant Soil 48 (1977) 447-454.

[9] Buttler A., Mitchell E.A.D., Freléchoux F., van der Knaap W.O., van Leeuwen J.F.N., Warner B.G., Gobat J.-M., Schweingruber F.H. Ruptures multiples dans les tourbières du Jura: changements climatiques et hydrologiques, successions végétales et impacts humains, Proceedings Symposium « Équilibres et ruptures dans les écosystèmes durant les 20 derniers millénaires en Europe de l'Ouest: Durabilité et mutation », Besançon, 18-22 septembre 2000, Annales littéraires de l'Université de Franche-Comté, 2001.

[10] Coutts M.P., Philipson J.J., The tolerance of tree roots to waterlogging. I. Survival of Sitka spruce and Lodgepole pine, New Phytol. 80 (1978) 63-69.

[11] Coutts M.P., Philipson J.J., The tolerance of tree roots to waterlogging. II. Adaptation of Sitka spruce and Lodgepole pine to waterlogged soil, New Phytol. 80 (1978) 71-77.

[12] Dang Q.L., Lieffers V.J., Assessment of patterns of response of tree ring growth of black spruce following peatland drainage, Can. J. For Res. 19 (1989) 924-929.

[13] Douglass A.E., Crossdating in Dendrochronology, J. For. 39 (1939) 825-831.

[14] Fankhauser A., Pollenanalytische Untersuchungen zur jüngsten Vegetationsgeschichte der Franches-Montagnes, Diplomarbeit, Universität Bern, 1995.

[15] Feldmeyer-Christe E., Étude phytoécologique des tourbières des Franches-Montagnes (cantons du Jura et de Berne, Suisse), Mater. Leve Geobot. Suisse 66 (1990) 1-163.

[16] Freléchoux F., Étude du boisement des tourbières hautes de la châne jurassienne : typologie et dynamique de la végétation - approche dendroécologique des peuplements arborescents, Thèse de doctorat, Université de Neuchâtel, 1997.

[17] Freléchoux F., Buttler A., Schweingruber F.H., Gobat J.-M., Stand structure, invasion and growth dynamics of bog pine (Pinus uncinata var. rotundata) in relation to peat cutting and drainage in the Jura Mountains, Switzerland, Can. J. For. Res. 30 (2000) 1114-1126.

[18] Freléchoux F., Buttler A., Gillet F., Dynamics of bog-pine-dominated mires in the Jura Mountains: a tentative scheme based on synusial phytosociology, Folia Geobot. 35 (2000) 273-288.

[19] Freléchoux F., Buttler A., Gillet F., Gobat J.-M., Succession from bog pine (Pinus uncinata var. rotundata) to Norway spruce (Picea abies) stands in relation to anthropic factors in Les Saignolis bog, Jura Mountains, Switzerland, Ann. For. Sci. 60 (2003) 347-356.

[20] Grünig A., Vetterli L., Wildi 0., Inventaire fédéral des hauts-marais et marais de transition d'importance nationale, Swiss Federal Institute for Forest, Snow and Landscape (WSL), CH-8903 Birmensdorf, 1984.

[21] Gunnarsson U., Rydin H., Demography and recruitment of Scots pine on raised bogs in Eastern Sweden and relationships to microhabitat differentiation, Wetlands 18 (1998) 133-141.
[22] Houghton J.T., Ding Y., Griggs D.J., Noguer M., van der Linden P.J., Xiaosu D. (Eds.), Climat Change: The Scientific Basis, IPCC Third Assessment Report, 2001.

[23] Hubschmid F., Lang G., Les Embreux, Holocene environments of a mire in the Swiss Jura Mountains, Diss. Bot. 87 (1985) 115-125.

[24] Ischer A., Les tourbières de la vallée des Ponts-de-Martel, Bull. Soc. Neuchatel. Sci. Nat. 60 (1935) 77-163.

[25] Joray M., L'étang de la Gruyère (Jura bernois), Étude pollenanalytique et statigraphique de la tourbière, Mater. Leve Geobot. Suisse 25 (1942) 1-117.

[26] Legendre P., Constrained clustering, in: Legendre P., Legendre L. (Eds.), Developments in numerical ecology, NATO ASI Series, Vol. G14, Springer Verlag, Berlin, 1987.

[27] Legendre P., Vaudor A., Le progiciel R., Analyse multidimensionnelle, analyse spatiale, Université de Montréal, 1991.

[28] Lieffers V.J., Rothwell R.L., Effects of depth of water table and substrate temperature on root and top growth of Picea mariana and Larix laricina seedlings, Can. J. For. Res. 16 (1986) 1201-1206.

[29] Lieffers V.J., Rothwell R.L., Rooting of peatland black spruce and tamarack in relation to depth of water table, Can. J. Bot. 65 (1987) 817-821.

[30] Lorimer C.G., Methodological considerations in the analysis of forest disturbance history, Can. J. For. Res. 15 (1985) 200-213.

[31] Matthey Y., Jacot-Descombes P., Les mesures de régénération et de cicatrisation des hauts-marais neuchâtelois, Premiers résultats et perspectives, Bull. Soc. Neuchatel. Sci. Nat. 119 (1996) 154-162.

[32] Mitchell E.A.D., van Der Knaap W.O., van Leeuven J.F.N., Buttler A., Warner B.G., Gobat J.-M., The palaeoecological history of the Praz-Rodet bog (Swiss Jura) based on pollen, plant macrofossils and testate Amoebae (Protozoa), The Holocene 11 (2001) 65-80.

[33] Oberdorfer E., Pflanzensoziologische Excursions Flora, Ulmer, Stuttgart, 1990.

[34] Payandeh B., Analysis of forest drainage experiment in northern Ontario. I. Growth analysis, Can. J. For. Res. 3 (1973) 387-398.

[35] Philipson J.J., Coutts M.P., The tolerance of tree roots to waterlogging, III. Oxygene transport in Lodgepole pine and Sitka spruce roots of primary structure, New Phytol. 80 (1978) 341-349.

[36] Philipson J.J., Coutts M.P., The tolerance of tree roots to waterlogging, IV. Oxygene transport in woody roots of sitka spruce and lodgepole pine, New Phytol. 85 (1980) 489-494.

[37] Rameau J.-C., Contribution phytoécologique et dynamique à l'étude des écosystèmes forestiers - Applications aux forêts du Nord-Est de la France, Thèse, Université de Besançon, No. 218, 1987.

[38] Reille M., L'origine de la station de pin à crochets de la tourbière de Pinet (Aude) et de quelques stations isolées de cet arbre dans les Vosges et le Jura, Bull. Soc. Bot. Fr. Lett. Bot. 138 (1991) 123-148.

[39] Richard J.-L., Les forêts acidophiles du Jura, Mat. Leve Geobot. Suisse 38 (1961) 1-164.

[40] Richardson D.M., Bond W.J., Determinant of plant distribution: Evidence from pine invasions, Am. Nat. 137 (1991) 639-668.

[41] Schweingruber F.H., Eckstein D., Serre-Bachet F., Bräcker O.U., Identification, presentation and interpretation of event years and pointer years in dendrochronology, Dendrochronologia 8 (1990) 9-38.

[42] Shotyk W., The peat bog archives of global environment change, in: Gupta A.K., Kerrich R. (Eds.), The Dynamic Earth. National Academy of Science Letters, India, 1994.

[43] Shotyk W., Cheburkin A.K., Appleby P.G., Fankhauser A., Kramer J.D., Lead in three peat bog profiles Jura Mountains, Switzerland Enrichment factor, isotopic composition, and chronology of atmospheric deposition, Water Air Pollut. 100 (1997) 297-310.

[44] Stanek W., Ontario clay belt peatlands - are they suitable for forest drainage? Can. J. For. Res. 7 (1977) 656-665

[45] Stokes M., Smiley T.L., An introduction to tree-ring dating, University Press, Chicago, 1968.

[46] Weber U.M., Computer-aided processing and graphical presentation of skeleton plots using commercial software packages, Dendrochronologia 12 (1994) 147-158.

[47] Weber U.M., Schweingruber F.H., A dendroecological reconstruction of western spruce budworm outbreaks (Choristoneura occidentalis) in the Front Range, Colorado, from 1720 to 1986, Trees 9 (1995) 204-213. 